\title{
Mining the resource of cross-presentation
}

\author{
Anne Hosmalin $1,2,3,4$ * \\ 1 INSERM U1016, Institut Cochin, Paris, France \\ ${ }^{2}$ CNRS UMR8104, Paris, France \\ ${ }^{3}$ University of Paris Descartes, Paris, France \\ ${ }^{4}$ Assistance Publique-Hôpitaux de Paris, Hôpital Cochin, Paris, France \\ ${ }^{*}$ Correspondence: anne.hosmalin@inserm.fr \\ Edited and reviewed by: \\ Kristian Michael Hargadon, Hampden-Sydney College, USA
}

Keywords: cross-presentation, dendritic cells, immunotherapy, tumors, HIV

\section{A commentary on}

On the role of dendritic cells versus other cells in inducing protective CD8 $+\mathrm{T}$ cell responses

by Zinkernagel RM (2014) Front Immunol 5:30. doi:10.3389/fimmu.2014.00030

(1) In the face of MHC-class I-restricted direct presentation from a live, replicating viral infection - after the groundbreaking discovery of the MHC restriction of $\mathrm{T}$ cell responses by Rolph Zinkernagel and Peter Doherty (1) cross-presentation is indeed a weaker phenomenon $(2,3)$. Antigen presenting cells can cross-present exogenous antigens from viruses which cannot infect them, allowing anti-viral MHCclass I-restricted, $\mathrm{CD}^{+}$, cytotoxic $\mathrm{T}$ cell priming (4). Nevertheless, when direct presentation is available, crosspresentation is dispensable for eliciting a maximal anti-vaccinia virus $\mathrm{CD} 8^{+} \mathrm{T}$ cell response (5).

(2) Demonstration of cross-priming often uses sensitive detection methods requiring the infusion of high numbers of $\mathrm{T}$ cell receptor-transgenic mouse $\mathrm{T}$ cells (3). However, in many studies, natural CD8 $\mathrm{T}$ cell responses to epitopic peptides were induced in mice by cross-priming (6-11).

(3) Dendritic cells (DC) and/or macrophages are indeed key transporters of antigens to secondary lymphoid organs (12-16).

(4) Via class I, DC present phagocytosed antigens from intracellular viruses, bacteria, and other microorganisms, but also from non-replicating microorganisms [HIV inactivated by antiprotease, replication level proven unable to induce direct presentation
(17)], apoptotic cells or tumor cellderived fragments (9), or even live cells [DC purified after culture with live tumor cells, then injected, and the wash-out from these cells, containing potentially contaminating antigen from these tumor cells, is not able to present directly (18)]. This can lead to protective vaccination against tumors (18-20).

(5) Location in secondary lymphoid organs or tertiary lymphatic tissues may indeed be the key to CD8 T cell priming. Any cell type may be able to prime CD8 $\mathrm{T}$ lymphocytes when located in lymphatic tissues and correctly activated (21-23). This in turn requires appropriate draining of these cells into lymphatic tissues to provide antigen amounts high enough for cross-presentation, in the presence of the appropriate costimulation and cytokines to induce either immune responses or active tolerance. This conjunction of circumstances may be obtained less rarely with DC than with other cell types, thanks to their high expression of class I molecules, costimulation molecules and cytokines, and their high propensity to transport antigens to lymphatic tissues. This can yield the direct presentation of endogenous epitopes. Why would not it also yield the cross-presentation of exogenous antigens?

(6) During HIV infection, like in LCMV infection, chronic type I IFN production and immune hyperactivation induce immune suppression. Live replicating recombinant vaccine vectors that induce efficient direct presentation are not acceptable for immune therapy in populations with potential immune deficiency, for safety reasons. In addition, these vectors require the use of sequences, which will not mutate like the actual patient's viral sequences. Why not try and exploit this opportunity to stir the balance of HIV-specific immune responses toward immunity instead of tolerance?

(7) Tumors also favor suppressive mechanisms (negative costimulation molecules like CTLA-4 and PD-1, suppressive cytokines like IL-10, myeloidderived suppressor cells). After tumor ablation, it may be hoped in the future to restore immune surveillance by anti-suppressive agents and therapeutic vaccination. Recombinant vaccines expressing tumor antigens for direct presentation require the use of sequences, which will not mutate like the actual patient's tumor antigen sequences. Antigens from dead tumor cells can be crosspresented, even though with a low efficiency, by DC, yielding protection against tumors in vivo (in experimental settings that are still artificial but protective) (9); this can be obtained more efficiently using live tumor cells (18). Why not try and exploit this opportunity to stir the balance of antitumoral immune responses toward immunity instead of tolerance?

(8) When major direct antigen presentation is not as blatant as during replicative viral infections, or is not exploitable for safety reasons, the alternative cross-presentation pathway may be exploitable for therapy.

\section{ACKNOWLEDGMENTS}

I acknowledge the Association de Recherche contre le Cancer (ARC), the Ligue de Recherche Contre le Cancer, 
CNRS-AP-HP-CHU Cochin collaboration, Université Paris Descartes, ANRS, Sidaction, the French Government's Investissement d'Avenir program, Laboratoire d'Excellence "Integrative Biology of Emerging Infectious Diseases" (ANR-10-LABX-62-IBEID).

\section{REFERENCES}

1. Zinkernagel RM, Doherty PC. Restriction of in vitro T-cell mediated cytotoxicity in lymphocytic choriomeningitis within a syngeneic or semiallogenic system. Nature (1974) 248:701-2. doi:10. 1038/248701a0

2. Zinkernagel RM. On cross-priming of MHC class I-specific CTL: rule or exception? Eur J Immunol (2002) 32(9):2385-92. doi:10.1002/1521-4141(200209)32:9<2385::AIDIMMU2385>3.0.CO;2-V

3. Zinkernagel RM. On the role of dendritic cells versus other cells in inducing protective CD8+ T cell responses. Front Immunol (2014) 5:30. doi:10. 3389/fimmu.2014.00030

4. Sigal LJ, Crotty S, Andino R, Rock KL. Cytotoxic T-cell immunity to virus-infected non-haematopoietic cells requires presentation of exogenous antigen. Nature (1999) 398(6722):77-80. doi:10.1038/18038

5. Xu RH, Remakus S, Ma X, Roscoe F, Sigal LJ. Direct presentation is sufficient for an efficient antiviral CD8+ T cell response. PLoS Pathog (2010) 6(2):e1000768. doi:10.1371/journal.ppat.1000768

6. Carbone FR, Bevan MJ. Class I-restricted processing and presentation of exogenous cell-associated antigen in vivo. J Exp Med (1990) 171(2):377-87. doi:10.1084/jem.171.2.377

7. Hosmalin A, Kumar S, Barnd D, Houghten R, Smith GE, Hughes SH, et al. Immunization with soluble protein-pulsed spleen cells induces class Irestricted cytotoxic $\mathrm{T}$ lymphocytes that recognize immunodominant epitopic peptides from Plasmodium falciparum and HIV-1. J Immunol (1992) 149(4):1311-8.

8. Le Bon A, Etchart N, Rossmann C, Ashton M, Hou S, Gewert D, et al. Cross-priming of CD8+ T cells stimulated by virus-induced type I interferon.
Nat Immunol (2003) 4(10):1009-15. doi:10.1038/ ni978

9. Goldszmid RS, Idoyaga J, Bravo AI, Steinman R, Mordoh J, Wainstok R. Dendritic cells charged with apoptotic tumor cells induce long-lived protective CD4+ and CD8+ $\mathrm{T}$ cell immunity against B16 melanoma. J Immunol (2003) 171(11):5940-7.

10. Matheoud D, Perié L, Vimeux L, Hoeffel G, Parent I, Marañon C, et al. Crosspresentation by dendritic cells from live cells induces protective immune responses in vivo. Blood (2010) 115:4412-20. doi: 10.1182/blood-2009-11-255935

11. Kerksiek KM, Niedergang F, Chavrier P, Busch DH Brocker T. Selective Racl inhibition in dendritic cells diminishes apoptotic cell uptake and crosspresentation in vivo. Blood (2005) 105(2):742-9. doi:10.1182/blood-2004-05-1891

12. Huang FP, Platt N, Wykes M, Major JR, Powell TJ, Jenkins CD, et al. A discrete subpopulation of dendritic cells transports apoptotic intestinal epithelial cells to $\mathrm{T}$ cell areas of mesenteric lymph nodes. J Exp Med (2000) 191(3):435-44. doi:10.1084/jem.191.3.435

13. Scheinecker C, McHugh R, Shevach EM, Germain RN. Constitutive presentation of a natural tissue autoantigen exclusively by dendritic cells in the draining lymph node. J Exp Med (2002) 196(8):1079-90. doi:10.1084/jem.20020991

14. Norbury CC, Malide D, Gibbs JS, Bennink JR, Yewdell JW. Visualizing priming of virus-specific CD8+ $\mathrm{T}$ cells by infected dendritic cells in vivo. Nat Immunol (2002) 3(3):265-71. doi:10.1038/ ni762

15. Belz GT, Shortman K, Bevan MJ, Heath WR CD8 $\{$ alpha $\}+$ dendritic cells selectively present MHC class I-restricted noncytolytic viral and intracellular bacterial antigens in vivo. J Immuno (2005) 175(1):196-200.

16. Kurts C, Heath WR, Carbone FR, Allison J, Miller JFAP, Kosaka H. Constitutive class-I restricted exogenous presentation of self antigens in vivo. $J$ Exp Med (1996) 184:923-30. doi:10.1084/jem.184. 3.923

17. Hoeffel G, Ripoche AC, Matheoud D, Gannagé $M$, Louis $S$, Nascimbeni $M$, et al. Antigen cross-presentation by plasmacytoid dendritic cells. Immunity (2007) 27:481-92. doi:10.1016/j. immuni.2007.07.021
18. Matheoud D, Baey C, Vimeux L, Tempez A, Valente M, Louche P, et al. Dendritic cells crosspresent antigens from live B16 cells more efficiently than from apoptotic cells and protect from melanoma in a therapeutic model. PLoS One (2011) 6(4):e19104. doi:10.1371/journal.pone.0019104

19. Albert ML. Death-defying immunity: do apoptotic cells influence antigen processing and presentation? Nat Rev Immunol (2004) 4(3):223-31. doi:10.1038/nri11308

20. Green DR, Ferguson T, Zitvogel L, Kroemer G. Immunogenic and tolerogenic cell death. Nat Rev Immunol (2009) 9(5):353-63. doi:10. 1038/nri2545

21. Kundig TM, Bachmann MF, DiPaolo C, Simard JJ, Battegay M, Lother H, et al. Fibroblasts as efficient antigen-presenting cells in lymphoid organs. Science (1995) 268(5215):1343-7. doi:10.1126/ science.7761853

22. Ochsenbein AF, Sierro S, Odermatt B, Pericin M, Karrer U, Hermans J, et al. Roles of tumour localization, second signals and cross priming in cytotoxic T-cell induction. Nature (2001) 411(6841):1058-64. doi:10.1038/35082583

23. Beauvillain C, Delneste Y, Scotet M, Peres A, Gascan $\mathrm{H}$, Guermonprez P, et al. Neutrophils efficiently cross-prime naive $\mathrm{T}$ cells in vivo. Blood (2007) 110(8):2965-73. doi:10.1182/blood-2006$12-063826$

Received: 28 January 2014; paper pending published: 31 January 2014; accepted: 03 February 2014; published online: 27 February 2014.

Citation: Hosmalin A (2014) Mining the resource of cross-presentation. Front. Immunol. 5:62. doi: 10.3389/fimmu.2014.00062

This article was submitted to Tumor Immunity, a section of the journal Frontiers in Immunology.

Copyright ( $(2014$ Hosmalin. This is an open-access article distributed under the terms of the Creative Commons Attribution License (CC BY). The use, distribution or reproduction in other forums is permitted, provided the original author(s) or licensor are credited and that the original publication in this journal is cited, in accordance with accepted academic practice. No use, distribution or reproduction is permitted which does not comply with these terms. 